\title{
Comparative Analysis Study of Snozelen Therapy and Five Senses Theraphy as an Alternative Therapy Using Multisensory Stimulation Factors: Focusing on Intervention Research on Snozelen Therapy
}

Seongeun Oh

Department of Health and Cosmetics, Dongduk Women's University, Seoul, Korea

Corresponding author: Seongeun Oh, Department of Health and Cosmetics, Dongduk Women's University, 60 Hwarangro, 13-gil, Seongbuk-gu, Seoul 02748, Korea

Tel.: +82 29404261

Fax: +82 29404186

Email: 9641234@naver.com

Received July 21, 2021

Revised August 24, 2021

Accepted September 15, 2021

Published September 30, 2021

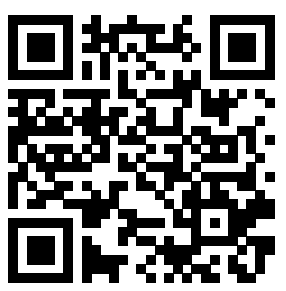

\begin{abstract}
Modern people inherently carry stress, psychological anxiety, and lack of communication. Therapy is a resource that can relieve stress and psychological anxiety for easing such tension. This is one of the reasons why modern people desperately need therapy. During the "healing" process through therapy, people experience an improvement in defense against diseases and natural healing, which leads to holistic treatment that integrates physical, psychological, social, and spiritual healing. Therapy has been widely used in five senses therapy that stimulates multiple sensations However, in addition to the five senses, Snoezelen therapy that includes dynamic sensations has recently emerged. Snozelen therapy can be applied as an interventional method for relaxation, stress prevention and management in the field of psychological health, as well as being more widely used as part of a variety of sensory stimulation therapies for people with physical problems.oThere are now numerous therapy pouring out for well-being and improved quality of life, but comparative research for perception, importance, and understanding of therapy has been insufficient, making it difficult to select the therapy that suits oneself. Therefore, we hope that the comparative analysis of Snoezelen therapy and five senses therapy in this study will serve as an opportunity to elevate the quality of life with the enhanced understanding and perception of therapy and more effective therapy treatment.
\end{abstract}

Keywords: Multiple sensations, Snoezelen therapy, Five senses therapy, Alternative treatment, Healing

\section{Introduction}

현대사회는 속도와 경쟁, 그리고 성공과 행복에의 강박이 지배하 는 사회이다. 이런 분위기에서 사람들은 억압되고 경직되며 소통을 잃어버리고 그 결과 서로 간에, 그리고 자기 자신으로부터도 소외되 어 살고 있다. 즉, 현대인들은 스트레스와 심리적 불안, 소통의 부재 를 내재하고 있다(Kim, 2020). 이러한 긴장을 이완시키는데 therapy 가 스트레스와 심리적 불안을 해소시켜 줄 수 있는 자원이다. 이는 현대인에게 therapy가 필요한 절실한 이유 중의 하나이다(Bae \& Lee, 2020).
21 세기 현대의학의 흐름은 '질병 중심 의학'에서 '건강 중심 의학' 으로 옮겨가고 있다. 건강 중심 의학이란 인간의 '웰빙(Well-being)' 을 추구하는 의학으로서 단순히 신체의 병변 부위의 질병만을 제거 하는 기존 의학의 한계를 넘어서는 것이다(Park \& Lee, 2019). 즉 환 자의 정신적·사회적·환경적 부분까지 고려하여 조화를 이루게 하는 전인적 치료를 의미한다. therapy는 이러한 전인적 치료의 하나로서 매우 효과적인 치료방법이 될 수 있다. 음악, 미술, 동작, 연극 등 다 양한 예술 활동이 환자의 질병뿐만 아니라 마음과 정신, 나아가 영혼 의 회복을 위한 좋은 치료 도구로 사용될 수 있기 때문이다. 예컨대 음악이나 동작은 사람을 자극하거나 반대로 안정시키는데, 직접적인 
생리적 반응을 불러일으키고 교감신경과 부교감신경을 아우르는 자 율신경계를 직접적으로 자극한다. 또한 자율신경계의 자극은 사람의 정서에 직접적인 영향을 미친다(Mesri \& Delepiane, 1991).

이렇듯 therapy를 통한 정서 수정은 행동학습과 변화의 필수적 요 소로 작용한다. 또한 몸과 영혼의 합일로서의 전인적 주체인 인간은 테라피를 통한 'healing' 과정에서 질병에 대한 방어능력과 자연 치유력의 향상을 경험하게 되는데, 그 결과 신체•심리•사회•영적 치 료를 통합하는 전인적 치료에 이르게 되는 것이다(Sholomov et al., 1991).

그동안의 테라피는 다감각을 자극하는 오감테라피가 많이 활용 되어 왔다. 오감테라피는 시각을 활용하는 color therapy, 후각의 aroma therapy, 청각의 music therapy, 촉각의 hydro therapy, 미 각의 food therapy 등이 있다.

그러나 최근에는 오감 외에도 신체의 위치에 대한 고유감각, 움직 임과 균형에 대한 전정감각, 그리고 내적 신체 상태에 대한 내부감각 까지 다루는 감각의 영역이 확장되고 있다(Dover \& Powers, 2003; Vignaux et al., 2015). 여기서 고유감각, 전정감각, 및 내부감각은 모두 동력과 관련되는 동적감각으로 볼 수 있는데, 동적감각은 신체 적 심리적 이완 등에 영향을 미칠 수 있는 중요한 역할을 수행한다.

스노젤렌은 오감에 동적감각을 더한 치료실 개념의 다감각 환경이 다. 스노젤렌에서의 감각들은 분리되어 있는 것이 아니라 한 공간 안 에 함께 존재하며, 시각-촉각, 청각-촉각, 후각-촉각, 시각-청각촉각 등 2-3가지 감각자극을 연결하여 제공한다. 3 가지 이상 감각자 극 시 단일 감각보다 더 극적이며, 멀티 감각은 몇년후에도 더 선명 한 해상도로 현재를 회상해 낼 만큼 뇌 기능 향상에 효과적이며, 그 외에 균형 능력, 사물 조작능력 및 기능적 수행능력 향상에 도움을 준다(Schofield, 2009).

이에 오감테라피의 오감에 동적감각을 가미한 치료형태의 스노젤 렌을 소개하고 오감테라피와의 비교, 분석 함으로써, 소비자들의 정 신적 이완에 더 효과적인 테라피를 선택하는데 도움을 주고 더 깊이 이해하는 계기가 되고자 한다.

\section{1. 스노젤렌(snoezelen) 개념}

네덜란드어로 'Schnuffeln (Sniffing; 킁킁거리며 냄새 맡다)'과 'ozelen (Dozing; 졸다)'이란 두 단어를 합성하여 만들어 낸 새로운 용 어로 'Schnuffeln'은 인간의 오감 즉 보고, 듣고, 냄새 맡고, 촉각으 로 느끼고, 맛보는 역동적인 활동을, 'ozelen' 은 안정감, 신체 접촉, 편안함 등과 같은 정서적인 감각 경험을 말한다. 따라서, 스노젤렌을 정의하면 정서적으로 안정된 곳에서의 활동과 환경에 대한 주의 깊은 탐색을 의미한다(Schofield, 2009).

스노젤렌(Snoezelen)은 다감각환경(multi-sensory environment), 다감각치료(multi-sensory therapy) 및 다감각자극 (multi-sensory stimulation) 등과 같은 용어로 사용되고 있다. 스노 젤렌은 시각, 후각, 청각, 촉각, 미각 및 전정 감각, 그리고 고유수용
성 감각을 자극하기 위한 특수 설비가 갖추어진 환경으로, 이곳에서 의 환경적 접근법을 사용하여 대상자의 적극적인 참여 유도 및 다양 한 감각을 경험할 수 있도록 하는 공간이다(Cuvo et al., 2001).

이런 다양한 감각활동을 할 수 있도록 설계된 공간에서 흥미 있는 분위기로 주변 탐색을 촉진하고, 안전하고 편안한 환경에서의 심신 을 이완 시키며, 억제받지 않은 분위기에 의해 스스로 즐길 수 있도 록 하는 것에 그 목적이 있다(Park et al., 2011).

스노젤렌 초기인 1970년 중반에는 감각 장애와 학습장애가 있 는 사람들에게 이완, 레저, 여가의 목적으로 주로 이용되어 왔지만 (Ashby et al., 1995; Slevin \& Mcclelland, 1999), 1995년 이후 전 세계적으로 요양 시설, 학교, 너싱홈, 병원, 복지관 등에 보급되면서 여가 활동의 목적뿐 아니라 인위적으로 조절된, 감각자극을 제공하 는 보완적인 치료 형태 등 다양한 목적으로 그 활용의 범위가 점점 확 대되고 있다(Park et al., 2011).

스노젤렌 적용 연구는 주로 환경적 접근이 필요한 아동 치매 환자 및 이완과 스트레스 관리를 요하는 정신과 환자들을 대상으로 하였 으며 대상자의 통증 관리와 간호 관리를 위해서도 활용되었다(Hope, 1998; Pinkney, 1997; Staal et al., 2007). Staal et al. (2007)은 단 기 노인 정신 병동에 입원 중인 중증도 치매 환자에게 스노젤렌을 적 용하여 일상생활활동(activities of daily living, $\mathrm{ADL}$ )과 정서 상태 가 호전된 것으로 보고하였다. 또한 van Weert et al. (2006)은 너싱 홈의 간호 인력에게 스노젤렌 공간을 경험하게 한 결과 자신의 업무 에서 더욱 긍정적인 성향을 가지게 된다고 보고하였다. 한편 국내에 서는 2000 년이 지나면서 스노젤렌이 학계에 발표되기 시작하였는데 발표된 연구의 대부분이 작업치료 분야이며 발표된 논문 편수도 많 지 않았다. 하지만, 정신지체아동과 발달장애 아동 치매노인을 대상 으로 한 이들의 연구에서 스노젤렌 적용으로 인해 참여자들의 자기 자극 행동이나 문제행동 이상행동이 서서히 감소하며, 이들의 정서 적 심리적 상태에 긍정적인 영향을 미친다고 보고 하였다(Yoo et al., 2005; Lee \& Yoo, 2006).

현재 국내에선 스노젤렌 공간이 재활병원이나 복지관 또는 노인 요양센터 등에 다양하게 보급되어 가고 있는 상황이며 해외에서는 스노젤렌에 대한 학문적 관심들이 집중되기 시작하여 의학(Manesh et al.,2015; Maseda et al., 2014; Sánchez et al., 2016), 간호학 (Schofield, 2009; Safavi et al., 2013; Cheng et al., 2017), 정신 심리학(Fava et al., 2010), 작업치료학(Taher et al., 2015; Seo et al., 2012), 건축학( Kim et al., 2015) 등 다양한 분야에서 스노젤렌 중재 연구가 진행되고 있는바, 정신건강 분야에서 이완, 스트레스 예 방 및 관리를 위한 중재법으로 적용될 수 있을 뿐 아니라 신체적 문제 를 가진 사람들에게도 다양한 감각 자극요법의 일환으로 더욱더 폭넓 게 활용될 수 있을 것이다.

\section{1) 스노젤렌의 유형}

스노젤렌은 시각, 후각, 청각, 촉각, 미각 및 전정감각 등의 다감 
각자극을 유발할 수 있는 하나의 구조화된 환경과 광섬유, 그물 그 네, 피아노 건반, 진동 침대 등의 자극 도구가 합쳐진 치료 형태의 다 감각 공간을 만들어 놓은 것으로 크게 multi sensory environment (MSE)와 multi sensory stimulation (MSS)로 구별된다.

시각, 후각, 청각, 촉각, 미각, 전정감각 등의 다감각자극을 유발할 수 있는 하나의 구조화된 환경에 촉각과 전정감각을 더하는 중재를 하는 것은 같은 점이나 $\mathrm{MSE}$ 는 공간(환경)에, $\mathrm{MSS}$ 는 자극 도구에 집 중하는 것이다.

$\mathrm{MSE}$ 는 참여자가 수동적으로 연구자가 정해놓은 프로그램에 따라 감각을 자극하는 것으로 연구자의 인식된 동기, 관심, 여가, 휴식, 치 료에 부합할 수 있는 환경을 구성하여 설계가 가능하며 감각 자극을 통제할 수 있으며, 휴식을 장려하여 신체•심리적 이완을 목표로 한 다.

$\mathrm{MSS}$ 는 그물 그네, 피아노 건반, 진동 침대 등을 참여자가 능동적 으로 순서와 관계없이 선택하여 만지거나 몸으로 체험하면서 다양한 감각들을 자유롭게 자극하는 것으로 변수가 많고 통제가 어렵다. 참 여자가 자극 도구(놀이기구)를 순서와 방법 등을 선택할 수 있는 것으 로 흥미로운 놀이를 통해 신체 및 심리적 각성을 목표로 한다. Table 1 는 스노젤렌의 유형을 정리한 것이다.

$\mathrm{MSE}$ 공간에서의 여러 감각은 동시적이며, 감각 간의 상호 협력과 상호보완적 작용에 의한 인지 현상이 발생하는데 이러한 작용을 공 감각이라 할 수 있으며, 복합 감각이라는 다감각의 상호 자극 안에서 이루어진다고 설명할 수 있다(Kim et al., 2014).

\section{2. 다감각}

1) 다감각 개념

인간의 감각은 신체 외부에서 오는 외부 감각과 신체 내부에서 오 는 내부 감각으로 나눌 수 있다. 외부 감각은 시각, 후각, 청각, 촉각, 미각의 오감으로, 신체 외부의 자극에 대한 반응을 처리하는 외향성 감각인 것에 비해, 내부감각은 신체 내부의 자극을 처리하는 것을 말 하며, 고유수용성 감각과 전정 감각이 이에 포함된다. 고유수용성 감 각이란 신체 내부의 근육과 관절의 축소, 확장, 구부림 또는 당김으 로써 사물의 무게감 및 신체의 위치를 감지하는 감각이며, 전정 감각 은 중력에 대한 정보를 감지함으로써 우리 신체의 속도감과 균형을 잡을 수 있도록 해주는 감각이다. 이 두 감각은 외부와 직접적으로 만나는 감각이 아닌 내부 감각으로써 다른 감각과 달리 거의 느끼지 못하거나 무조건 반사로 이루어지는 경우가 많으며, 특히 몸의 움직 임과 자세, 속도를 감지하도록 한다는 점에서 중요한 역할을 담당한

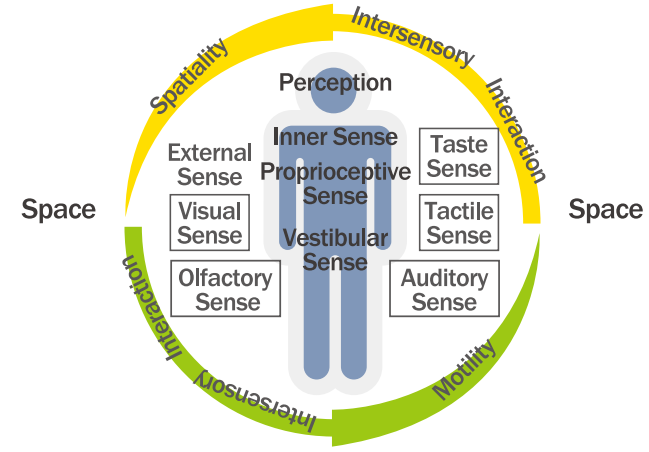

Figure 1. Multi-sensory interaction

다(Jung \& $\mathrm{Na}$, 2007).

다감각(multi-sensory)이란 감관 영역(感官領域)의 자극으로 여러 감각이 서로 깊은 연관이 되어있는 현상으로, 외부감각과 내부감각 을 통해 외적 대상을 인식하고 움직임을 통해 행위를 유발하는 감각 적인 성질이 모인 하나의 복합체로 환경과 교류하고 상호작용하게 된 다(Choi \& Kim, 2018).

환경과 주체가 서로 관계하는 접촉 자극은 공간 지각의 직접적인 체험으로 행위를 유발하고 복합적인 감각체계의 자극을 통해 개인의 감성을 촉진시킴으로써 감각의 중첩과 전이 작용을 한다. 이러한 촉 각적 시감각의 감응적 메커니즘에 접촉 자극의 감성을 가촉성(可觸 性)이라고 하며, 질감과 무게, 온도를 읽어내고 만짐으로써 공간과 장소, 시간에 대해 상호작용을 한다. 공간에서 가촉성 영역은 재료의 본성을 잃지 않고 오히려 증대 시키는 방향으로 다양하게 변형시킨 다. 하나의 감각으로 통합되는 행위를 통해 인간의 다양한 감정을 수 렴하고 다른 이에게 자연스럽게 표현할 수 있게 되어 감정의 해방에 효과적인 치유의 과정을 경험하게 한다(Kim et al., 2014; Figure 1).

2) 다감각 효과

(1) 감각과 지각의 확장

다감각이 관여하는 감각 간의 교호적 작용에 관계하여 Maurice Merleau-Ponty는 '지각의 현상학(Phenomenologie de la Perception)'에서 "맹인의 지팡이는 더 이상 맹인에게는 하나의 대상 물, 즉 단순한 객체적 물체가 아니다. 지팡이 끝은 감각의 영역이 되 어 촉각의 범위와 반경을 연장 시키고 시감각의 유사 기관이 된다."

Table 1. Types of snoezelen

\begin{tabular}{llcccc}
\hline Type & Goal & Researcher & Participants & Intensive & \multicolumn{2}{c}{$\begin{array}{c}\text { Control of sensory } \\
\text { stimulus }\end{array}$} \\
MSE & Relaxation & Active & Passive & Environment & \\
MSS & Awakening & Passive & Active & Stimulation Tool & $\times$ \\
\hline
\end{tabular}




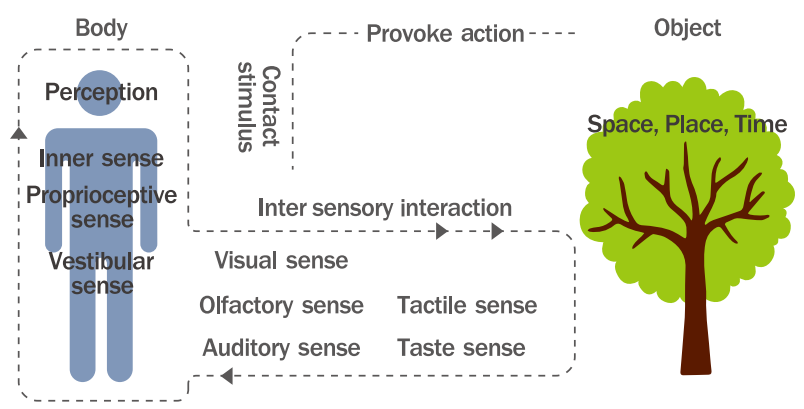

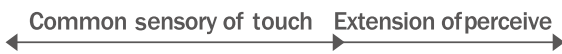

Figure 2. Extension of perceive and common sensory of touch

라고 언급하였다. 맹인에게 지팡이는 시각적 역할을 대행하고 손안 에 쥐어진 손잡이의 접점은 손바닥의 피부로부터 시작되지만 온 신경 은 지팡이를 붙잡고 있는 손바닥과 손잡이와의 접점에서 시작하여 지 팡이의 몸통을 통해 도로의 표면까지 연결되어 있다. 도로의 정보는 다시 역행하여 지팡이라는 매개체의 몸통을 통과하여 손끝으로 전달 될 것이고 감각의 정보는 다시 몸의 말초 신경을 관통하여 두뇌로 전 달된다(Kim et al., 2014)(Figure 2).

맹인은 매 순간 이러한 촉각적 운동감각에 의존하며, 손의 감각뿐 아니라 발바닥, 그리고 온몸에 퍼져있는 촉각기관과 주변의 소리에 의한 청각, 냄새의 후각 정보까지 그에게 도움을 준다. 이는 시각을 제외한 모든 감각이 그를 돕고 있음을 알 수 있다(Shin, 2010).

이처럼 우리는 다감각의 협력적 관계를 인정하지 않을 수 없다. 감 각은 하나의 작용이 아닌 다감각적 자극에 의한 협력적 작용으로 일 어나며, 또한 다감각이라는 감각의 확장을 의미할 뿐만 아니라 지각 의 확장을 의미하기도 한다.
(2) 시간의 반복적 재배열

감각은 감각함에서 끝나는 것이 아니라 시간성을 가지고 과거, 현 재, 미래에 관여하여 체험자의 의식에 끊임없이 영향을 주게 된다. 신체의 감각기관에 의해 감각된 것은 기억과 같은 정신적인 것과도 관계를 맺는다고 볼 수 있다. 그래서 우리는 새로운 상황에 접했을 때, 과거에 경험하여 지각한 것들에 대한 기억의 연상을 통하여 새 로운 상황에 대한 감각들이 더해져 지각을 하게 된다(Lee \& Choi, 2008). 지각한다는 것은 시간 속 기억을 바탕으로 과거의 상황을 통 해 현재를 보고 경험하는 현재와 시간의 연속성을 가진 미래로 연결 되는 것이다. 지각의 변화와 기억의 연상은 움직임을 통해 촉각적 공 간으로 끌어들인다. 우리는 시간의 연속체에서 끊임없이 재배열 、 재 구성되어 공간에 능동적인 의미를 부여한다. 오늘날 빠르게 흘러가 는 시간의 경험은 정신적 파괴를 가져오고 있다.

이처럼 기억과 직접적인 조작에 의한 자극의 재구성을 통해 감각 들을 활성화 시키고 트라우마의 재현과 기억을 되풀이함으로써 마음 속에 반복되는 행위들의 정서 지향적 접근으로 인해 자기중심적인 치 유의 과정을 겪게 된다.

\section{(3) 상호 관계적 지각}

감각은 공간을 구성하고 있으며 공존이라는 개념으로도 이야기된 다. 맹인이나 청각장애인들도 잔존 감각으로 공존하는 공간을 경험 할 수 있다. 이는 공간이 시각적인 것에만 한정되는 것이 아니라 촉 각적인 공간도 있고, 청각적인 공간도 존재하고 있음을 말하며, 결국 공간의 다질적인 의미를 설명하고 있는 것이다(Jung \& So, 2010).

이처럼 하나의 감각이 다른 감각의 작용을 불러일으키는 것을 공 감각이라고 하며, 자신의 몸 공간성은 그저 자신의 몸 범위 내에 머 물지 않고 바깥 환경의 사물들 속으로 전이되어 간다.

또한 인간과 공간이 상호 작용을 하면서 다양한 지각 경험으로 개

Table 2. The multisensory element of snoezelen

\begin{tabular}{|c|c|c|c|}
\hline Sensory & Kinds & Snoezelen's equipment & Researcher \\
\hline Visual & $\begin{array}{l}\text { Physical properties of hue, Brightness, } \\
\text { Saturation, Hue, Shape, Texture, Pattern }\end{array}$ & $\begin{array}{l}\text { Buble tube, Fiber optics, } \\
\text { Mirror ball, Beam projector, } \\
\text { Ball pool, Spot light }\end{array}$ & $\begin{array}{l}\text { Fava \& Straus, 2010; } \\
\text { Klages et al., } 2011\end{array}$ \\
\hline Olfactory & Smell, Incense & $\begin{array}{l}\text { Aroma diffuser, Smell of nature } \\
\text { (flowers, trees flowerpots, etc,) }\end{array}$ & $\begin{array}{l}\text { Manesh et al., 2015; } \\
\text { Sánchez et al., } 2016\end{array}$ \\
\hline Auditory & Wave, Sound, Sound wave & $\begin{array}{l}\text { Half vibrating bed, Water column } \\
\text { Fruit sound set, Animal sounds set } \\
\text { Drum, Piano keyboard }\end{array}$ & Schofield, 2009 \\
\hline Taste & Sweet, Salty, Sour, Bitter, Spicy & $\begin{array}{l}\text { Citrus fruit, Sherbet } \\
\text { Dried fruit, Popcorn }\end{array}$ & $\begin{array}{l}\text { Collier et al., 2010; Taher et } \\
\text { al., } 2015\end{array}$ \\
\hline Tactile & $\begin{array}{l}\text { Pain sensation, Pressure sensation, } \\
\text { Cooling sensation, Warmth sensation, }\end{array}$ & $\begin{array}{l}\text { Tactile plate, Doll } \\
\text { Cushion, blanket } \\
\text { Water bed }\end{array}$ & Safavi et al., 2013 \\
\hline Motor & Vestibular sense proprioception & $\begin{array}{l}\text { Therapy chair, Glider bolster } \\
\text { Flying hammock, Full body swing } \\
\text { Bolster swing }\end{array}$ & Safavi et al., 2013 \\
\hline
\end{tabular}


인의 감성을 충족하고 신체의 참여를 유발하여 관심이 집중되는 몰입 의 과정을 거치게 된다. 이러한 현상은 시각적, 촉각적, 운동적, 다질 적인 측면들을 통해 새로운 도구들과 매개하여 몸을 통해 다양한 공 간적 가치를 지니게 된다. 하나의 통일된 많은 자극을 받아들이고 반 응할 때 몸 전체는 움직임이 일관되고 조화로운 방식으로 하나로 통 일된 것처럼 감각하고 움직인다. 몸은 행동의 주체로써 감각과 운동 으로 결합되어 있으며, 감각과 운동은 개별이 아닌 전체로써 변화하 는 체계를 형성하고 있어 감각에 의해 운동이 달라지기도 하고 운동 에 의해 감각이 달라지기도 한다. 노래를 부를 때 얼굴 표정의 변화 와 몸동작에 변화를 주는 것은 이러한 행동의 변화에 의한 감각의 변 화를 말해 주는 것이다. 공간과 신체의 상호 관계를 통한 공간 지각 의 다변화적 특성은 신체에 의한 이동과 움직임의 변화를 유발하여 유동적 공간을 체험하게 한다(Nam, 2016). 이런 다감각효과를 극대 화할 수 있도록 인위적으로 창조된 스노젤렌은 오감과 동적감각을 자 극하기 위한 도구들로 구성되어 있다.

\section{3. 스노젤렌 공간구성}

\section{1) 스노젤렌의 다감각 요소}

위에서 설명한 각각의 감각들은 분리되어 있는 것이 아니라 한 공 간 안에 함께 존재하며, 시각-촉각, 청각-촉각, 후각-촉각, 시각청각-촉각 등 2-3가지 감각자극을 연결하여 제공한다.

3 가지 이상 감각자극 시 단일 감각보다 더 극적이며, 멀티 감각은 몇 년후에도 더 선명한 해상도로 현재를 회상해 낼 만큼 뇌 기능 향상 에 효과적이며, 그 외에 균형 능력, 사물 조작능력 및 기능적 수행능 력 향상에 도움을 준다(Gersten et al., 2000; Kater, 1989)(Table 2).

\section{2) 자극도구}

인위적으로 감각을 자극하기 위해 만들어진 환경(공간)은 신뢰된 분위기를 생산하기 위해선 스노젤렌 주변의 소음이 없고 의자, 바닥 등이 안락하며 적절한 온도 유지와 환기가 잘되어 있어야 한다. 청 각, 촉각 자극을 위해 율동적으로 흔들리는 기구와 음악을 준비하고, 시각 자극을 위해 자연환경에서는 볼 수 없는 광섬유와 조명 장비 를 갖추고 조절기로 강화 또는 감소를 할 수 있도록 한다(Pagliano, 2017).

다음의 자극도구들은 홍익무역(Hongik, Korea)에서 제조된 것이 고, 시각을 위한 도구로 물기둥, 광섬유, 미러볼 등이 사용되며 구체 적 내용은 다음과 같다.

(1) 물기둥

물기둥은 버블 튜브 $(150 \times 16 \mathrm{~cm}$; Hongik) 라고도 불리며 규칙적 이고 꾸준하게 제공되는 물방울이 시각적 자극과 심리적 안정을 유도 한다. 여러 가지 색깔이 번쩍거리는 기포들에 의해 시각적 자극을 먼 저 받고 시간이 흐른 뒤 열과 진동으로 인한 청각, 촉각적 자극도 느 낄 수 있다. 유리관에 손과 얼굴을 비비면서 따뜻함과 진동을 느낄 수 있고 기포가 흐르면서 뽀글거리는 소리로 청각적 자극도 느낄 수
있다(Pagliano, 2017).

(2) 광섬유

광섬유(end glow fiber optic cable, $0.5 \mathrm{~mm} \times 2 \mathrm{~m}, 500 \mathrm{PCSX}$; Hongik)는 빛을 발산하는 광섬유 다발로 섬유는 뜨겁지도 않고 건드 려도 안전해서 원하는 위치에 놓고 만지거나 몸에 두르면서 사용하며 집중과 차분한 분위기를 조성할 수 있다(Pagliano, 2017).

(3) 미러볼

미러볼 $(17 \times 17 \times 12.8 \mathrm{~cm}$; Hongik, Korea $)$ 은 몽환적이고도 신 비로운 공간 연출을 할 수있어 상상력 등을 자극하는 데 도움이 된다 (Pagliano, 2017).

(4) 촉각 도구

촉각을 위해 양모러그, 면쿠션, 면담요 등이 사용된다. 양모러그 $(160 \times 200 \mathrm{~cm})$ 는 흡습성, 보온성과 탄성이 우수하며 촉감이 부드 러운 천연소재로 편안하고 포근함을 느낄 수 있고(Manni et al.., 2010), 면 쿠션 $(50 \times 70 \mathrm{~cm}$, Hongik)과 면 담요 $(100 \times 200 \mathrm{~cm}$, Hongik)는 우리나라 성인 중 $80 \%$ 가 가장 선호하는 섬유이다(Meng \& Choi, 2021).

\section{(5) 후각 도구}

아로마 디퓨저(Maison, France)는 후각을 위한 도구로써, Note 와 향의 조합이 잘 맞는 버가못, 라벤더, 일랑일랑 $6 \mathrm{~mL}$ 를 $2: 3: 1$ 의 비 율로 물 $300 \mathrm{~mL}$ 에 희석하여 사용하며, 스트레스 감소와 심리적 안녕 감 등의 이완을 도모할 수 있다 (Kim \& Lee, 2014).

(6) 청각도구

청각을 위한 테라피뮤직은 인간이 느끼는 편안한 심박수와 비슷한 템포(60-80 bpm)를 가진 휴식하기 좋은(50-60 db)의 음향으로 안 정되고 평안한 상태에 처하게 하여 신체적, 심리적 긴장 이완을 가져 온다(Clarke et al., 2019).

(7) 미각도구

미각을 위해 시트러스계 과일이 사용되며(Collier et al., 2010), 전 정감각을 위해 흔들의자 형태의 테라피 쿠션 의자 $(85 \times 150 \times 100 \mathrm{~cm}$, Hongik) 로 신체를 완벽하게 지지하고 감싸주어 특유의 안정감과 편 안함을 느낄 수 있게 한(Pagliano, 2017).

\section{3) 스노젤렌의 공간}

Robins (2001)은 이상적인 치료공간에 대하여 "정돈되어 있으면서 도 자극적이고 안전하게 보이면서도 권유하는 느낌이 드는 환경이다" 라고 하며 "공간의 크기는 너무 크거나 작지 않아야 한다"라고 하였 다.

Yun \& Chai (2012) 연구에서 개인 치료실의 크기는 $3 \mathrm{~m} \times 3.5$ $\mathrm{m}-3.6 \mathrm{~m} \times 4.5 \mathrm{~m}$ 가 적당하고, 스노젤렌의 벽과 천정은 빛의 효과 


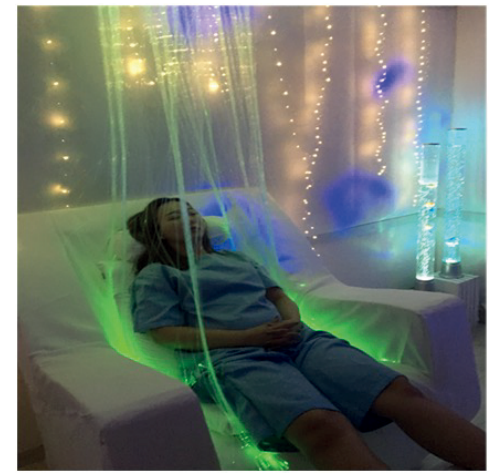

Figure 3. 2 Way interaction of MSE therapy

를 더욱 두드러지게 하기 위해 흰색을 사용하며, 여기에 시각적, 촉 각적, 청각적, 후각적, 미각적 등 다감각적인 자극을 탐색할 수 있도 록 한다. 방 전체가 편안하게 느껴져야 하기 때문에 벽과 천정의 색 은 매우 중요한 역할을 하고 있고, 화려함보다는 아늑함을 우선한다.

\section{4. 스노젤렌 테라피 vs 오감 테라피}

\section{1) 스노젤렌 테라피}

스노젤렌은 다감각을 활용한 환경이며, 이곳에서의 휴식을 스노젤 렌 테라피로 정의한다. 참여자가 스노젤렌에 들어서면 물기둥, 미러 볼, 별 커튼, 아로마 향기, 자연을 담은 음악 등의 다양한 감각을 처 음 느끼고, 테라피 의자까지의 경로엔 양모 매트, 면 시트와 면 쿠션 의 부드러움을 접촉하고 제공되는 오렌지가 미각세포를 자극한다. 스윙이 되는 테라피 의자에 앉아 다감각을 체험하면서 30 분간 휴식 한다(Figure 3).

\section{2) 오감 테라피}

오감(五感) 테라피는 시각, 후각, 청각, 촉각, 미각을 활용한 치유 법이며, 스노젤렌은 오감 테라피에 동적 감각을 가미한 치유공간이 다. 한마디로, 스노젤렌과 오감 테라피의 차이는 동적 감각의 유무이 며 각 감각의 구체적 내용은 다음과 같다.

시각의 대체요법을 color therapy라 한다. 색채가 가진 일정한 물 리적 파동과 시각적 자극을 통해 중추 신경계를 활성화시켜 심리적 안정과 몸의 밸런스를 잡아주는 것으로, 물리적 요소, 심리적 요소, 조화와 조합의 요소, 직관과 자극의 요소 등의 방법이 있다. 또한 그 림 치료, 조명 치료, 스타일 치료가 병행되기도 한다.

후각의 대체요법을 aroma therapy라 하며, 식물의 꽃, 잎, 줄기, 씨앗, 뿌리 등에서 추출된 정유(essential oil)를 이용한다. 치료법으 로는 마사지법, 흡입법, 목욕법, 습포법, 스팀법 등이 있다.

청각의 대체요법을 music therapy라 하고, 정신과 신체 건강의 복 원(rehabilitation) 및 유지(maintenance)하며 향상(habilitation) 시 키기 위한 프로그램으로 의료 요법과 정신과적 요법으로 구분된다. 의료 음악요법으로는 환경음악 요법, 관조 음악요법, 조합 음악요법, 연주 의료 음악요법, 창조 음악요법, COS, IMT 법 등이 있다. 정신 과적 음악요법으로는 정신 역동적 요법, 정신 분석적 요법, 형태론적 요법, 통합적 음악요법 등이 있다.

촉각의 대체요법은 massage \& hydrotherapy라 하며, 마사지와 수치료 등이 있다. 수치료는 수 혈증(hydropathy)이라고도 하고 물 치료(water cure)라고도 한다. 수 치료는 통증 완화 및 치료를 위해 물을 사용하는 대체 의학, 작업 치료 및 물리 치료의 일부이다. 재활 의학 분야에서 사용되던 프로그램을 일반화 시킨 것으로 물의 다양한 형태들, 즉 고체(얼음), 액체, 기체(증기) 형태로 활용한다. 사우나, 샤워, 입욕, 좌욕, 월풀(whirlpool), 습포(hot moist pack) 법 등이 있 다.

오감의 마지막 감각인 미각은 food therapy로 인체의 방어력과 면 역력을 높여주는 자연 치유 요법이며 음식을 통하여 육체와 정신의 질병을 치료하는 음식 요법이다. 또한, 푸드 테라피는 음식이 지닌 여러 성질을 이용하여 심신의 질병을 예방하고 건강을 증진시키는 방 법을 통칭하는 자연 치유법으로 기존의 약선학, 민간요법, 식이요법 등의 다양한 방법을 포괄하고 있으며 섭취 가능한 모든 음식을 대상 으로 건강에 유익하도록 하는 대체 요법이다.

동적 감각은 스노젤렌테라피에 포함되는 감각으로 전정감각과 고 유감각을 말한다. 동적 감각 운동은 약화된 전정 기능을 중추신경 (뇌)에서 보상(compensation)하는 과정을 촉진시켜 증세를 빨리 없 애고 평형 능력을 증대시키며 일상생활에서의 활동을 극대화하는 것 이다. 여러 매달리는 도구들(그물 그네, 편평한 그네, 개구리 그네, 기둥 모양 그네)을 주로 이용하여 치료하게 되며, 그 외에도 스쿠터 보드, 치료용 큰 공, 볼풀, 부는 종류의 장난감, 일반적인 장난감 등 을 이용하기도 한다.

이러한 오감과 동적 감각을 활용한 스노젤렌과 오감 테라피는 감 각의 확장성, 상호보완성, 치유성이라는 같은 점이 있으나, 다른 점 도 존재하며 구체적 차이점은 다음과 같다

\section{3) 스노젤렌 테라피과 오감 테라피의 차이점 \\ (1) 공간의 의미 \\ 가. 스노젤렌 테라피의 위계성}

위계의 개념은 동일한 종류의 요소 혹은 비교될 수 있는 요소들 사 이에 존재하는 크기와 형상-위치의 차이를 말한다. 즉, 예외적인 크 기, 독특한 형상, 중요한 위치는 어떠한 형태나 공간이 시각적으로 독특하게 보이도록 하며 하나의 공간 조직에서 중요한 것으로 인식되 도록 하므로 위계를 높이는 요인들이다. 그리고 여러 가지의 구성 요 소를 구비해 격식을 갖춘 공간이나 건축물은 그렇지 못한 것보다 위 계가 높다고 간주된다(Ching, 2015). 
나. 오감 테라피의 추상성

오감 테라피 시 정형화된 공간은 불필요하고 기(氣)와 에너지의 공 감각(共感覺, synesthesia)이 흐른다(Choi, 2014).

\section{(2) 감각의 능동성}

가. 스노젤렌 테라피의 능동적 촉각

능동적 촉각은 능동적으로 사물의 특성을 탐색하는 경험 (exploratory touching)을 의미하며 특히 감각의 수동성과 능동성을 구분하는 매개로써 운동 감각을 중시한다. 가령 어떤 뾰쪽한 물체가 지각자의 피부를 자극하면 '찌르는 감각'을 느끼지만(수동적 촉각), 지각자 스스로 뾰쪽한 물체의 끝을 느낀다면 찌르는 감각 자체로서가 아니라 '뾰쪽한 물체'를 느끼게 되는 것이다. 이 같은 촉각 경험의 차 이는 지각자가 피부의 감각적 인상에 초점을 두는가, 아니면 감각을 발생시키는 사물에 초점을 두는가의 차이로 나타나는데, 감각의 능 동적 특성은 환경에 있는 물체에 관한 정보를 수집하는 데 있어 수동 적 촉각보다 우수함을 시사한다(Yuk \& Kim, 2017).

\section{나. 오감 테라피의 수동적 촉각}

지각자의 자발적 움직임이 없이 수동적으로 피부에 경험되는 자극 (being touched)을 말한다(Yuk \& Kim, 2017).

\section{(3) 치유 형태}

스노젤렌은 통합적 테라피를 지향하고, 오감 테라피는 개별적 테 라피와 통합적 테라피 모두가 가능하다.

이처럼 스노젤렌은 휴식의 즉각적인 제공이 가능하고, 능동적 촉 각으로 탐색적 인지 기능을 향상시키고(Kang, 2015), 동적 감각의 발달은 각성을 낮춰 정서적 안정에 효과적이다.

각성 수준은 수면과 밀접한 관련이 있어 각성수준 조절의 실패는 수면의 실패로 이어지기 때문에, 망상체의 각성을 증가시키거나 과 민반응을 줄이는 감각 통합적 접근이 수면 안정화에 이르게 한다. 또 한, 동적 감각의 발달은 근 긴장도를 억제하여 피로감과 스트레스를 감소시킨다(Kwon \& Rhie, 2018).

\section{Conclusion}

복잡한 현대사회에서의 신체적, 정신적 긴장으로 인해 많은 질환 이 나타나고 있으며 이러한 문제점을 개선하기 위한 오감테라피와 스 노젤렌테라피의 활용을 위한 비교, 분석을 하였다.

공통점으로는 다감각을 이용한 감각의 확장성, 상호보완성, 치유 성이다. 차이점으로는 자극감각, 공간의 의미, 감각의 능동성여부 및 치유형태등으로 볼수 있다. 오감테라피의 자극감각은 시각, 후각, 미 각, 청각, 촉각이며, 공간은 꼭 필요한 것이 아닌 추상성으로 존재할 수 있으며 촉각은 중재자에 의해 얻어지는 수동적 촉각이며 치유형태
는 각각의 오감이 개별적인 테라피를 할 수도 있고 여러 개의 테라피 를 통합적으로 대체요법으로 활용할 수 있다.

반면, 스노젤렌테라피의 자극 감각은 시각, 후각, 미각, 청각, 촉각 및 동적 감각이고 이런, 다감각이 통합적으로 치유하는 형태를 지니 며, 테라피 공간이 꼭 존재해야 하는것과 능 동적 촉각이 사용되는 것 의 차이점이 있다.

현재 웰빙과 삶의 질 향상을 위한 많은 테라피가 우후죽순처럼 쏟 아지지만, 테라피에 대한 인식, 중요도, 이해를 위한 비교연구는 미 진한 실정에서 자신에게 맞는 테라피를 선택하는데 어려움이 있었 다. 따라서 본 연구자는 스노젤렌테라피와 오감테라피의 비교분석을 통한 테라피의 이해와 인식개선, 좀더 효과적인 테라피로 삶의 질이 향상되는 계기가 되기를 기대한다.

This work is Seongun Oh's M.S. thesis at the Dongduk Women's University, Seoul, Korea.

\section{Author's contribution}

SEO designed and wrote manuscript.

\section{Author details}

Seongeun Oh (Graduate student), Department of Health and Cosmetics, Dongduk Women's University, 60 Hwarangro, 13-gil, Seongbuk-gu, Seoul 02748, Korea.

\section{References}

Ashby M, Lindsay WR, Pitcaithly D, Broxholme, Geelen N. Snoezelen: its effects on concentration and responsiveness in people with profound multiple handicaps. British Journal of Occupational Therapy, 58: 303-307, 1995.

Bae MN, Lee MS. Phenomenological study on volunteer experiences in auriculotherapy for middle-aged women. Asian Journal of Beauty and Cosmetology, 18: 27-39, 2020.

Cheng SC, Hsu WS, Shen SH, Hsu MC, Lin MF. Dose response relationships of multisensory intervention on hospitalized patients with chronic schizophrenia. Journal of Nursing Research, 25: 13-20, 2017.

Ching FDK. Architecture: form, Space, \& Order (4th edition). John Wiley, New Jersey, p14, 2015.

Choi SS. A study on the design methodology of the multi therapy based on the Yin-yang five elements theory: 
focusing on 'Tae gwa' and 'Bul geup' of the Yin-yang five elements theory by the four pillars of destiny. Journal of Digital Design, 14: 991 - 1,006, 2014.

Choi SJ, Kim DH. A study on the planning elderly care facility considering multi-sensory stimulation. Korean Institute of Interior Design Journal, 20: 151-156, 2018.

Clarke CG. Grace L, Harky A. Music therapy following cardiac surgery. Interactive CardioVascular and Thoracic Surgery, 28: 722-727, 2019.

Collier L, Mcpherson K, Ellis-Hill C, Staall J, Bucks R. Multisensory stimulation to improve functional performance in moderate to severe dementia-interim results. American Journal of Alzheimer's Disease and Other Dementias, 25: 698-703, 2010.

Cuvo AJ, May ME, Post TM. Effects of living room, snoezelen room, and outdoor activities on stereotypic behavior and engagement by adults with profound mental retardation. Research in Developmental Disabilities, 22: 183-204, 2001.

Dover G, Powers ME. Reliability of joint position sense and force reproduction measures during internal and external rotation of the shoulder. Journal of Athletic Training, 38: 304-310, 2003.

Fava L, Straus K. Multi-sensory rooms: comparing effects of the snoezelen and the stimulus preference environment on the behavior of adult with profound mental retardation. Research in Developmental Disabilities, 31: 160-171, 2010.

Gersten RM, Baker S, Lloyd JW. Designing high-quality research in special education group experimental design. The Journal of Special Education, 34: 2-18, 2000.

Hope KW. The effects of multisensory environments on older people with dementia. Journal of Psychiatric and Mental Health Nursing, 5: 377-385, 1998.

Jung HW, Nah KA. A study on the meaning of sensibility and vocabulary system for sensibility evaluation. Journal of the Ergonomics Society of Korea, 26: 17-25, 2007.

Jung SS, So BI. A study on the phenomenological method of the expression in Tadao Ando architecture: focused on space expression element through phenomenology of perception of Merleau-Ponty. Journal of the Architectural Institute of Korea, 26: 31-38, 2010.

Kang BJ. A study on the scientific foundation of multi-modal senses in art education. Art Education Review, 53: 1-26,
2015.

Kater KM. Response of head-injured patients to sensory stimulation. Western Journal of Nursing Research, 11: 2033, 1989.

Kim JM, Seo KS, Kim MH. A study on the multi-sensory stimulation of aroma and color temperature effects on neuro-energy. Journal of the Korea Academia-Industrial cooperation Society, 6: 3579-3586, 2015.

Kim HJ, Kim JH, Lee JS. A study on the art care space applying multi-sensory stimulating elements. Journal of Korea Institute of Spatial Design, 9: 63-73, 2014.

Kim HY, Lee S. Effects of aromatherapy on anxiety and sleep of inpatients with coronary angiography. Journal of People, Plants and Environment, 17: 457-463, 2014.

Kim MJ. The effect of spa massage on subjective satisfaction and improvement in quality of life for clients of skin care salons. Asian Journal of Beauty and Cosmetology, 18:107$117,2020$.

Klages K, Hobson S, Orange JB, Zecevic A. Potential of snoezelen room multisensory stimulation to improve balance in individuals with dementia: a feasibility randomized controlled trial. Clinical Rehabilitation, 25: 607-616, 2011.

Kwon HS, Rhie SJ. Effects of sensory integration activities on body scheme and body self-concept of preschoolers with developmental delays. Journal of Special Education, 43: 251-270, 2018.

Lee C, Choi YJ. A study on the sense space by Merleau-Ponty's Phenomenological body perception. Korean Institute of Interior Design Journal, 17: 39-46, 2008.

Lee JY, Yoo EY. The effects of implementation of multisensory environments (Snoezelen) on the emotional state of college students. Korean Journal of Occupational Therapy, 14: 39-47, 2006.

Manni B, Gitlin L, Garzetta G, Collier L, Fabbo A. Occupational therapy in nursing home. In: Occupational therapy for older people. Pozzi C, Lanzoni A, Graff MJL, Morandi A (Eds). Springer International Publishing, Switzerland, pp101-124, 2020.

Manesh MJ, Kalti M, Hosseini F. Snoezelen room and childbirth outcome. Iranian Red Crescent Medical Journal, 17: e18373, 2015.

Nam Y. Experience of 'Being-with' by Interactive art: focusing on Rafael Lozano-Hemmer's body movies. Journal of the 
Association of Western Art History, 44: 211-234, 2016.

Maseda A, Sánchez A, Marante MP, González-Abraldes I, Buján A, Millán-Calenti JC. Effects of multisensory stimulation on a sample of institutionalized elderly people with dementia diagnosis: a controlled longitudinal trial. American Journal of Alzheimer's Disease and Other Dementias, 29: 463473, 2014.

Meng Y, Choi JM. A comparative study on the subjective sensation and tactile preferences for casual shirt fabrics compared by the nationality of female university students. Korean Journal of the Science of Emotion \& Sensibility, 24: 105-114, 2014.

Mesri JC, Delepiane C. Colour and photosensitive epilepsy. Medicina, 51: 327-330, 1991.

Park YR, Oh DN, DN, Kim KS, Kim JA, Wee H. The analysis of intervention studies for snoezelen. The Korean Journal of Rehabilitation Nursing, 14: 95-102, 2011.

Park JY, Lee MS. Influence of beauty care on well-being-oriented behaviors and well-aging behaviors in adult men. Asian Journal of Beauty and Cosmetology, 17: 93-106, 2019.

Pagliano P. Multisensory environments. David Fulton Publishers, New York, pp52-93, 2017.

Pinkney LA. Comparison of the snoezelen environment and a music relaxation group on the mood and behaviour of patients with senile dementia. British Journal of Occupational Therapy, 60: 209-212, 1997.

Sholomov II, Cherevashchenko LA, Suprunov OV, Raĭgorondskii IM. Possibilities of transcranial magnetic therapy and color and rhythm therapy in rehabilitation of ischemic stroke. Zhurnal Nevrologii I psikhiatrii S.S. Korsakova, 109: 23-28, 1991.

Safavi M, Yahyavi H, Farahani H, Mahmoudi N, Mahboubinia M. The effect of multi-sensory stimulation (MSS) on cognitive status of women with Alzheimer's disease in Fereshtegan elderly care center. Pars Jahrom University of Medical Sciences, 11: 39-45, 2013.

Sánchez A, Maseda A, Marante-Moar MP, de Labra C, LorenzoLópez L, Millán-Calenti JC. Comparing the effects of multisensory stimulation and individualized music sessions on elderly people with severe dementia. Journal of Alzheimers Disease, 52: 303-315, 2016.

Seo HJ, Won JK, Jung YJ, Lee SA. The influence of Snoezelen program on depression of college students: a prior study. The Journal of Korean Academy of Mental Health in
Occupational Therapy, 2: 17-26, 2012.

Schofield P. Snoezelen within a palliative care day setting: a randomized controlled trial investigating the potential. International Journal on Disability and Human Development, 8: 59-65, 2009.

Shin HJ. The perception of depth in the phenomenological constitution of space- husserl s affective relief and Merleau-Pontys perceptive itinerary. Journal of Humanities, Seoul National, 64: 131-162, 2010.

Slevin E, McClelland A. Multisensory environments: are they therapeutic? A single-subject evaluation of the clinical effectiveness of a multisensory environment. Journal of Clinical Nursing, 8: 48-56, 1999.

Staal JA, Sacks A, Matheis R, Collier L, Calia T, Hanif H, Kofman ES. The effects of Snoezelen (multi-sensory behavior therapy) and psychiatric care on agitation, apathy, and activities of daily living in dementia patients on a short term geriatric psychiatric inpatient unit. International Journal of Psychiatry in Medicine, 37: 357-370, 2007.

Taher AV, Ahmadi MK, Zamir FP. Effects of multisensory stimulation on cognition function, depression, anxiety and quality of life in elderly persons with dementia. International Journal of Sport Studies, 5: 355-360, 2015.

Vignaux G, Besnard S, Denise P, Elefteriou F. The vestibular system: a newly identified regulator of bone Homeostasis Acting Through the Sympathetic Nervous System. Current Osteoporosis Reports, 13: 198-205, 2015.

van Weert JC, Janssen BM, van Dulmen AM, Spreeuwenberg PMM, Bensing JM, Ribbe MW. Nursing assistants' behavior during morning care: effects of the implementation of Snoezelen integrated in 24-hour dementia care. Journal of Advanced Nursing, 53: 656-668, 2006.

Yoo EY, Lee, JY, Hwang SY. Outcomes of a multisensory environments for older people with dementia. Journal of Korean Society of Occupational Therapy, 13: 33-42, 2005.

Yun WY, Chai CG. A study on the planning of the composition and the area of the neuroscience center in general hospital. Journal of The Korea Institute of Healthcare Architecture, 18: 35-43, 2012.

Yuk HS, Kim MJ. The usefullness of haptic virtuality: from visible virtuality to haptic virtuality. Cogito, 83: 146-174, 2017. 


\section{국문초록}

\section{다감각자극 요소에 의한 대체요법으로의 스노젤렌 테라피와 오감테라피의 비교 분석 연구: 스노젤렌 중재연구 중심으로}

오성은

동덕여자대학교 보건향장학과, 서울, 한국

현대인들은 스트레스와 심리적 불안, 소통의 부재를 내재하고 있다. 이러한 긴장을 이완시키는데 테라피가 절실히 필요하다. 몸과 영혼의 합일로서의 전인적 주체인 인간은 테라피를 통한 'healing'과정에서 질병에 대한 방어능력과 자연치유력의 향상을 경험하게 되는데, 그 결과 신체•심리·사회•영적 치료를 통합하는 전인적 치료에 이르게 되는 것이다. 그동안의 테라피는 다감각을 자극하는 오감테라피가 많이 활용되어 왔다. 그러나 최근에는 오감 외에도 신체의 위치에 대한 고유감각, 움직임과 균형에 대한 전정감각, 그 리고 내적 신체 상태에 대한 내부감각까지 다루는 감각의 영역이 확장된 스노젤렌 테라피가 도입되었다. 스노젤렌 테라피는 정신 건강 분야에서 이완, 스트레스 예방 및 관리를 위한 중재법으로 적용될 수 있을 뿐 아니라 신체적 문제를 가진 사람들에게도 다양 한 감각 자극요법의 일환으로 더욱더 폭넓게 활용되어지고 있다. 현재 웰빙과 삶의 질 향상을 위한 많은 테라피가 우후죽순처럼 쏟 아지지만, 테라피에 대한 인식, 중요도, 이해를 위한 비교연구는 미진한 실정에서 자신에게 맞는 테라피를 선택하는데 어려움이 있 었다. 따라서 본 연구는 스노젤렌테라피와 오감테라피의 비교분석을 통한 테라피의 이해와 인식개선, 좀더 효과적인 테라피로 삶의 질이 향상되는 계기가 되기를 기대한다.

핵심어: 다감각, 스노젤렌 테라피, 오감테라피, 대체요법, 힐링

\section{참고문헌}

강병직. 미술 교육에서 '다양한 감각' 활용의 과학적 근거에 대한 고찰. 조형교육, 53: 1-26, 2018.

권현실, 이숙정. 감각통합활동이 발달지체유아의 신체도식과 신체적 자아개념에 미치는 영향. 특수교육논총지, 43: 251$270,2018$.

김문주. Spa Massage 체험이 고객의 주관적 만족도와 삶의 질 향상에 미치는 영향에 대한 연구. 아시안뷰티화장품학술지,

18: 107-117, 2020.

김정민, 서광수, 김명호. 아로마 및 색온도의 다감각자극이 뉴로에너지에 미치는 영향 . 한국산학기술학회논문지, $16:$

$3,579-3,586,2015$.

김현주, 김주연, 이종세. 다감각요소룰 적용한 아트케어 공간에 대한 연구. 한국공간디자인학회지, 9: 63-73, 2014.

김혜연, 이숙. 아로마 흡입법이 관상동맥 조영술 대상자의 불안 및 수면에 미치는 효과. 인간식물환경학회지, 17: 457-

463, 2014

남이랑. 상호작용적 예술을 통한 '함께-있음'의 경험. 서양미술사학회지, 44: 211-234, 2016.

멍위, 최종명. 여대생의 국적에 따른 캐주얼 셔츠 소재의 주관적 감각과 촉감 선호도 비교. 감성과학24: 105-114, 2014. 박재영, 이명선. 성인 남성의 미용관리가 웰빙지향 행동과 웰에이징 행위에 미치는 영향. 아시안뷰티화장품학술지,

17:93-106, 2019.

박영례, 오두남, 김금순, 김진아, 위휘. 스노젤렌 중재연구 논문분석. 재활간호학회지, 14: 95-102, 2011.

배미녀, 이명선, 중년여성의 이혈(耳穴)자원봉사 경험에 대한 현상학적 연구. 아시안뷰티화장품학술지, 18: 27-39,

2020. 
서혜정, 원재경, 정예지, 이성아.. 스노젤렌(Snoezelen) 프로그램이 대학생의 우울감에 미치는 영향 사전연구. 한국정신 보건작업치료 학회지, 2: 17-26, 2012.

신호재. 현상학적 공간구성에서 깊이 지각. 후설의 촉발적 부조와 메를로-퐁티의 지각의 여로. 인문논총, $64: 131-162$, 2010.

유은영, 이지연, 황수연. 치매 노인을 위한 다감각환경(snoezelen) 프로 그램의 적용 효과. 대한작업치료학회지, 13: 3342,2005

육현승, 김문조. 햅틱의 가상성과 그 유용성에 대하여 시각적 가상에서 햅틱 가상으로. 코기토, 83: $146-174,2017$.

윤우용, 채철균. 종합병원 뇌신경센터의 공간구성 및 면적계획에 관한 연구. 한국의료복지건축학회 논문집. $18: 35-43$, 2012.

이상헌. 스노젤렌(Snoezelen) 공간이 중증도 정신지체 아동의 자기자극 행동에 미치는 치료적 영향. 대한작업치료학회지, 12: 73-81, 2004.

이지연, 유은영. 스트레스 관리접으로서의 다감각환경(스노젤렌) 적용이 정서 상태에 미치는 영향. 대한작업치료학회지, 14: 39-47, 2006.

이찬, 최영재. 메를로-퐁티의 신체지각을 통한 감성 공간 연구. 한국 실내디자인학회지, 17: 39-46, 2008. 정진원, 소병일. 안도 타다오 건축의 現象學的 表現方法에 관한 연구. 대한건축학회지, 26: 31-38, 2010. 정현원, 나건. 감성 평가를 위한 감성의 의미 재정립과 어휘 체계에 관한 연구. 대한인간공학회지, $26: 17-25,2007$.

최성수. 음양오행론을 활용한 오감 멀티 테라피 디자인 방법론 연구: 사주명리학에 근거한 음양오행의 태과와 불급을 중심 으로. 디지털디자인학연구, 14: 991-1006, 2014.

최수진, 김동훈. 다감각자극을 고려한 노인요양시설 실내계획에 관한 연구. 한국실내디자인학회지, 20: 151-156, 2018. 


\section{中文摘要}

\section{Snozelen疗法与五官疗法作为多感官刺激因素替代疗法的对比分析研究：以 Snozelen疗法的干预研究为重点}

吳誠恩

同德女子大学保健香妆学科, 首尔, 韩国

现代人天生就有压力、心理焦虑和缺乏沟通。治疗是一种资源，可以缓解压力和心理焦虑，缓解这种紧张。这 就是现代人迫切需要治疗的原因之一。在通过治疗进行“治愈”的过程中, 人们经历了疾病防御和自然治愈的改 善, 这导致了综合身体、心理、社会和精神治疗的整体治疗。治疗已广泛应用于刺激多种感觉的五官疗法, 然 而, 除了五官之外, 最近出现了包括动态感觉的Snozelen疗法。Snozelen疗法可作为心理健康领域放松、压力 预防和管理的介入方法, 此外, 还被更广泛地用作针对身体有问题的人的各种感觉刺激疗法的一部分。其他疗 法目前有许多疗法, 旨在改善健康和生活质量, 但对疗法的感知、重要性和理解的比较研究还不够, 使选择适 合自己的疗法变得困难。因此, 我们希望本研究中对Snozelen疗法和五官疗法的对比分析将作为一个机会, 通 过提高对治疗的理解和感知以及更有效的治疗来提高生活质量。

关键词: 多重感觉, 鼻塞疗法, 五感疗法, 替代疗法, 愈合 